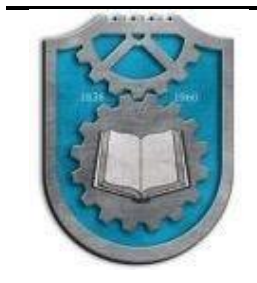

MOBILITY \& VEHICLE MECHANICS

DOI: $10.24874 / \mathrm{mvm} .2021 .47 .03 .01$

UDC: $627.51: 502$

\title{
ENVIRONMENTAL PROBLEMS AND THEIR SOLUTION DURING CONSTRUCTION AND OPERATION OF ST. PETERSBURG BARRIER FLOOD PROTECTION
}

\author{
Victor I. Popov ${ }^{1}$, Lev M. Monosov ${ }^{2}$, Igor V. Polischuk ${ }^{3}$
}

Received in July $2020 \quad$ Revised in August $2020 \quad$ Accepted in September 2020

RESEARCH ARTICLE

\begin{abstract}
The report concerns the problems of ecology in the Eastern part of the Gulf of Finland and the Neva Bay during the construction and operation of St. Petersburg Barrie Flood Protection (KZS). The Barrier of Flood Protection includes 11 stone-earth dams, 2 ship-pass and 6 water-pass, a bridge with a lifting span of $102 \mathrm{~m}$ long and an underwater road tunnel with a length of about $2 \mathrm{~km}$. The developed KZS project provides free water exchange, which has a minimal impact on the hydraulic regime and ecology of the water area of the Neva Bay. The protective structures fully implemented a systematic approach to collect, divert and clean up the entire volume of polluted water from the marine section of the ring road around St. Petersburg. KZS does not have a negative impact on the sanitary regime of the Neva Bay, on the reproduction of fish stocks, including valuable fish species. Moreover, protective structures play a huge role in preserving biodiversity and rare species of near-water and waterfowl.
\end{abstract}

KEY WORDS: flood, barrier of flood protection, ecology, dams

(C) 2021 Published by University of Kragujevac, Faculty of Engineering

\footnotetext{
${ }^{I}$ Victor I. Popov, PhD., Moscow State Motor and Road Technical University (MADI), Leningradsky prospect, 64, Moscow, Russia, vpopov@stpr.ru (*Corresponding author)

${ }^{2}$ Lev M. Monosov, PhD., Directorate of St. Petersburg Barrier Flood Protection (KZS), Torzkovskay str.5, St.Petersburg, Russia, lev monosov@inbox.ru

${ }^{3}$ Igor V. Polischuk, Eng., Directorate of St. Petersburg Barrier Flood Protection (KZS), Torzkovskay str.5, St.Petersburg,Russia, ipol@fkpkzs.ru
} 


\section{PROBLEMI ŽIVOTNE SREDINE I NJIHOVO REŠENJE TOKOM IZGRADNJE I RADA BARIJERE ZA ZAŠTITU OD POPLAVA SANKT- PETERBURGA}

REZIME: U radu se analizira probleme ekologije u istočnom delu Finskog zaliva i Nevskog zaliva tokom izgradnje i rada barijere za zaštitu od poplava Sankt Peterburga (KZS). Barijera za zaštitu od poplava obuhvata 11 brana od kamene i zemlje, 2 brodska i 6 rečnih prelaza, pokretni most dužine $102 \mathrm{~m}$ i podvodni tunel dužine oko $2 \mathrm{~km}$. Razvijeni projekat KZS obezbeđuje slobodan tok vode, što ima minimalan uticaj na hidraulični režim i ekologiju vodotokova Nevskog zaliva. Zaštitne konstrukcije su u potpunosti primenile sistematski pristup prikupljanja, preusmeravanja i čišćenju celokupne količine zagađene vode sa morske deonice obilaznice oko St. Peterburga. KZS nema negativan uticaj na sanitarni režim Nevskog zaliva, na reprodukciju ribljeg fonda, uključujući vredne vrste riba. Štaviše, zaštitne strukture igraju ogromnu ulogu u očuvanju biodiverziteta i retkih vrsta ptica.

KLJUČNE REČI: poplava, barijera zaštite od poplava, ekologija, brane 


\section{ENVIRONMENTAL PROBLEMS AND THEIR SOLUTION DURING CONSTRUCTION AND OPERATION OF ST. PETERSBURG BARRIER FLOOD PROTECTION}

Victor I. Popov, Lev M. Monosov, Igor V. Polischuk

\section{INTRODUCTION}

In 2020, nine years have passed since the commissioning of St. Petersburg Barrier of Flood Protection (KZS). The KZS is an extended marine hydraulic structure built in the freezing Gulf of Finland. Its length is more than $25 \mathrm{~km}$, with $17.5 \mathrm{~km}$ passing through the open water area of the Eastern part of the Gulf of Finland. High-speed road on the 11 stone and earthen dams, 6 culverts, 2 navigation structures C-1 and C-2 spans of $200 \mathrm{~m}$ and $116 \mathrm{~m}$ respectively, tunnel under navigation structure C-1 length $1961 \mathrm{~m}$, steel bridge with lift span over the navigation structure $\mathrm{C}-2$, the approach channels to the navigation structures $\mathrm{C}-1$ and C-2, office of the KZS on the island Kotlin with the Central panel of the flood warning system KZS are included (Figure 1). During the 317 years of St. Petersburg's existence, there have been more than 300 rises in the water level above the $160 \mathrm{~cm}$ mark of the Baltic system, which considered as floods. Among them are three disastrous ones in 1777.1824 and 1924 .The most exceptional flood in height $(\mathrm{H}=421 \mathrm{~m})$ occurred on November 19 , 1824 and was called the "flood". Two-thirds of the city's territory was flooded and more than 20 people was killed of this flood. The Flood of 1924 stimulated the development of a project to protect Leningrad from floods (Figure 2). In 1972-1976 years by the Institute Lengidroproekt was developed technical project of KZS. 52 design and survey and research institutes of the USSR took part in its creation. The project by the State expertise and by the government of the USSR in December 1978. In 1979, the construction of the protective complex began was approved.

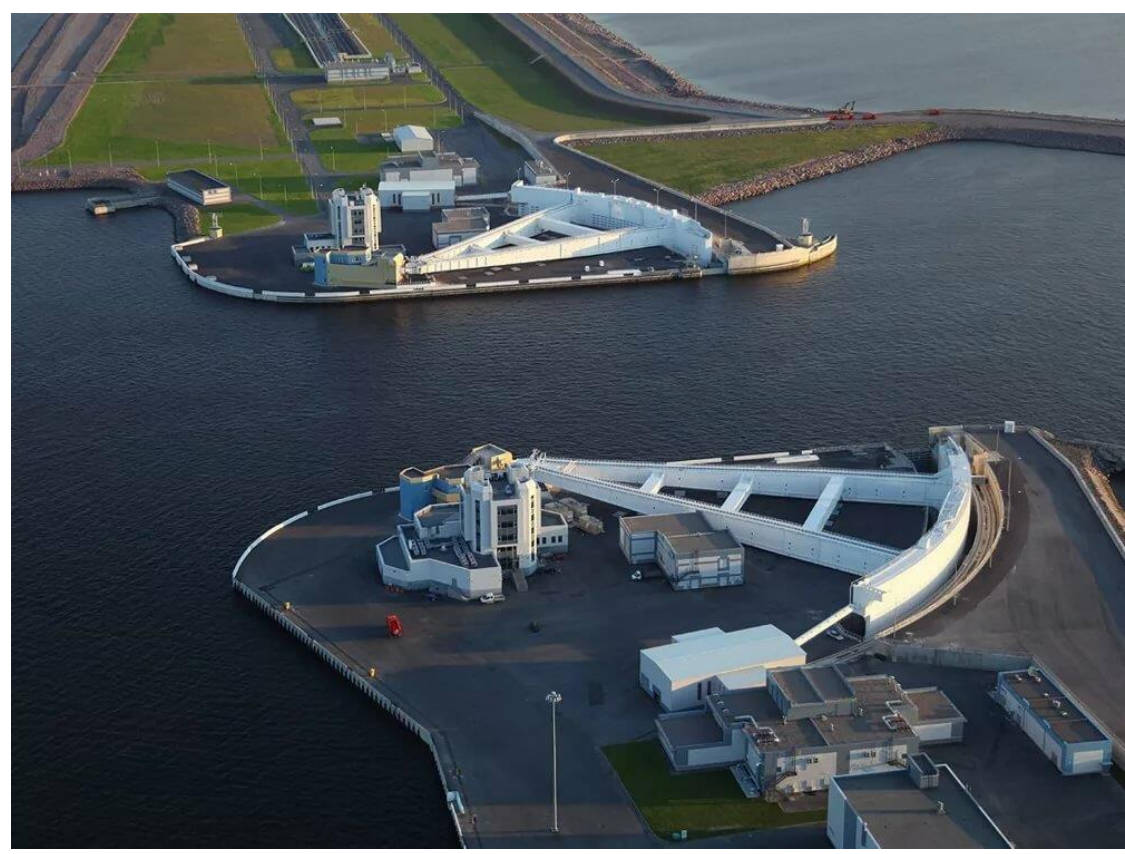

Figure 1 Navigation structures $C$ - 1 


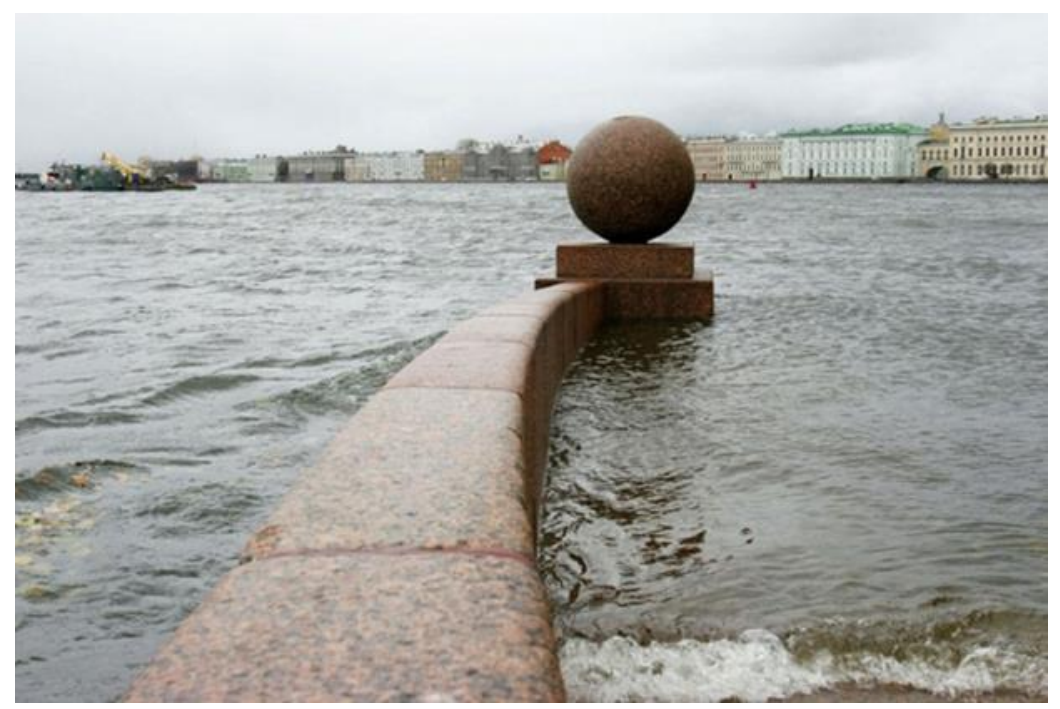

Figure 2 Typical flood in St. Petersburg

At this time, a number of well-known experts claimed that the construction of protective structures led to a violation of the hydrodynamic, hydrochemical and hydrobiological relationship of the Finland Gulf and the Neva Bay. At the same time, they attributed the deterioration of the sanitary condition of the Neva Bay to the construction of protective structures, and not to a sharp increase in concentrated discharges into the Northern channels of the Neva river Delta from centralized treatment facilities. However the Neva Bay is merged with the Finland Gulf by two Straits: the Northern and Southern gates, which have extensive shoals that prevent the penetration of sea wind waves and wind currents into the Neva Bay, the removal of ice from the Bay To the Gulf, and hinder water exchange between fresh and brackish waters of the Bay. Therefore, the Neva Bay is essentially a closed basin, which has always formed a local hydrological regime, little affected by the Gulf of Finland. Some experts believed that floods contribute to the purification of the Neva Bay and the Delta of the Neva. As shown numerous field tests a result of intensive cyclonic activity during floods in the Eastern part of the Finland Gulf there has always been a mixing of waters and a retreat to the West of the wedge of brackish water (from 30 to $90 \mathrm{~km}$ ) from the target of protective structures and therefore their statements should be considered incorrect. The design solutions implemented correctly during the construction process did not change the system of currents, wave and temperature regimes, or the natural regime of water levels in the Neva Bay and the Delta of the river. Neva. As in everyday life, the project provided levels well below the ordinary (Figure 3). 


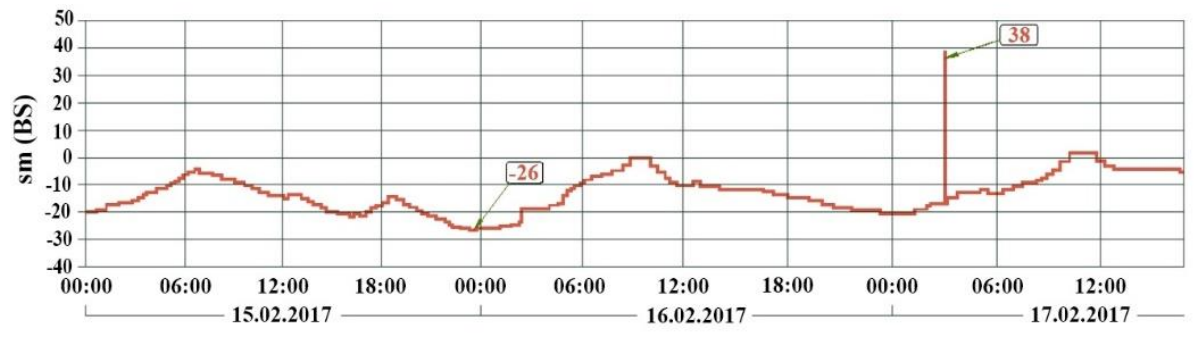

Time

Figure 3 Water Level below the ordinary on the date of 15.02.2017.

Insufficiently justified public statements of well-known experts provoked in the late 80-ies of the last century in the society an acute discussion on the problems of environmental safety of the complex of protective structures under construction. As a result, in October 1990, the Leningrad authorities decided to suspend the construction of the KZS.

\section{ENVIRONMENTAL ASPECTS OF THE KZS PROJECT}

In 2004, the Russian Government entered into a loan agreement with the EBRD to finance the completion of the KZS. Considering that the project has not been conserved for 14 years, the unfinished objects have actually become a source of environmental pollution of the Neva Bay. Leading Russian specialists, as well as foreign experts from the UK (Halkrou) and the Netherlands (Roal Haskoning) were involved in the development of the project documentation for the completion of the KZS. The completion project contained a section on the environmental justification of the facility (environmental Protection). The construction of the barrier began in 2006. 6 contracts were concluded on the basis of standard FIDIC contracts (red and yellow books). Since the beginning of the construction of the KZS, the problem of pollution was gradually decrease and contribute to this the conditions created for the completion of the construction of KZS facilities. During the operation of the Complex, as well as during the construction period, environmental issues were also much attention was paid [1]. The required quality of environmental safety was also monitored by environmental experts from the EBRD occasionally visited the facility under construction. Also constant supervision was provided for the government Agency for technological and environmental monitoring (Rostekhnadzor of Russia). In 2010, the KZS Directorate issued decisions on granting a water body for use, which defined a safety zone, including an environmental zone in the Baltic sea. The total area of this zone, for which the KZS Directorate is responsible, is 21 square $\mathrm{km}$. The main threat to the adjacent water basin during the operation of the KZS is surface water runoff (diffusive runoff) from the roadway of the marine section of the ring road. On this section of $25.4 \mathrm{~km}$ long, the six-lane highway is capable of passing up to 27,500 vehicles per day at an estimated speed of $120 \mathrm{~km} / \mathrm{h}$. Taking into account the high and increasing traffic intensity along the highway every year, a systematic approach was developed and implemented to collect, divert and clean up the entire volume of polluted water. These large-scale measures made it possible to prevent the discharge of untreated sewage into the water area. The complexity of the organizing task for collection and treatment of effluents from the entire KZS was associated with extremely limited areas of dams and the presence of six bridges on the route at the culverts and at the C-2 ship-passing structure of the drawbridge and a deep-water road tunnel (Fig.4) [1, 2]. System of drainage pipes and trays placed above the bridge are intended for clean the diffusion runoff from the roadway of bridges over culverts. Water supplied for cleaning in 
special combined filter cartridges filled with clinoptilolite (a mineral from the Kholinsky Deposit of Buryatia) and activated carbon. 118 such filter cartridges are installed on the bridge supports.

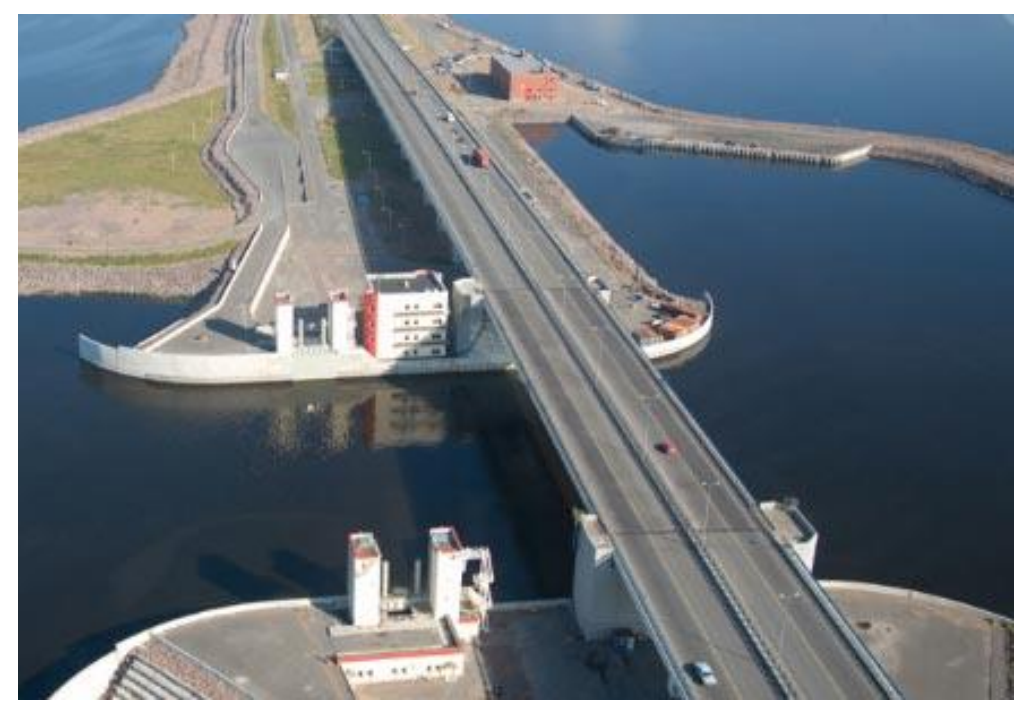

Figure 4 Drawbridge with ship-passing structure $C-2$

To treat wastewater entering a deep-water road tunnel, a water removal system is used, which consists of water-collecting drainage trays, receptacles of receiving tanks for collection and pumping, three pumping stations, and treatment facilities. The main pollutants present in the surface runoff of the tunnel are mineral and organic impurities of natural origin, substances of natural origin in various phase-dispersed States, petroleum products, washed - out components of road surfaces, heavy metal compounds, surfactants (synthetic surfactants), bacterial contamination. A mandatory element of surface treatment facilities is an accumulating sump. Treatment facilities of the road tunnel S-1 KZS provide for physical and chemical treatment of surface runoff after the accumulating sump. The coagulation process with subsequent water filtration allowed to obtain purified water at the outlet with the indicators established by the standards for fish and farm reservoirs. Discharge of treated water from treatment facilities to the water area is made if its composition meets the regulatory requirements for suspended substances, biochemical oxygen consumption, chlorides and petroleum products. Sufficient to say, that all local treatment facilities used at the KZS produced in Saint Petersburg. They are resistant to low temperatures and corrosion. It can be stated, that at present the KZS Directorate has implemented a plan of water protection measures in accordance with the requirements of the Water code and the Water strategy of Russia for the period up to 2025. For the first time in Europe, $100 \%$ treatment of surface runoff from the long sea section of the KZS highway has been provided, and water enters the Baltic sea only after it has been cleared of pollution. These measures are an important part of the Russian party's implementation of the Convention for the protection of the marine environment of the Baltic sea area (Helsinki Convention) and its recommendations to reduce discharges from urban areas by properly regulating the stormwater system. The operated complex of structures to protect Saint Petersburg from flooding does not adversely affect the sanitary regime of the Neva Bay, on the reproduction of fish stocks, including valuable passing and semi-passing fish. The 
process of sustainable restoration of the ecosystem in the KZS zone after the completion of the construction period has been stable. This evidence that is preservation of living conditions for almost 60 species of aquatic and near-water birds that migrate annually through the Gulf of Finland (Figure 5) [3, 4]. In the areas immediately adjacent to the protective structures, there is an annual appearance in the spring of white and black swans, Curlews, capercaillie, terns and other birds listed in the Red book, as well as the appearance of predatory mammals - red foxes and weasels. A permanent approach to ship and culvert structures of the seal KZS (Pinipedia) is noted (Figure 6).

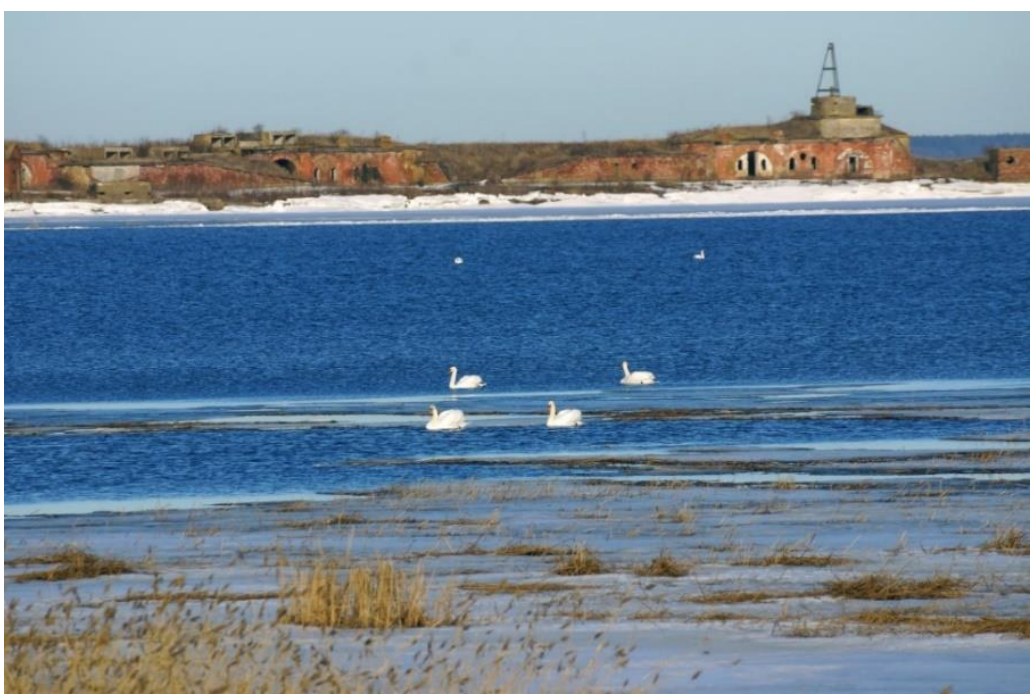

Figure 5 Swans in the Gulf of Finland
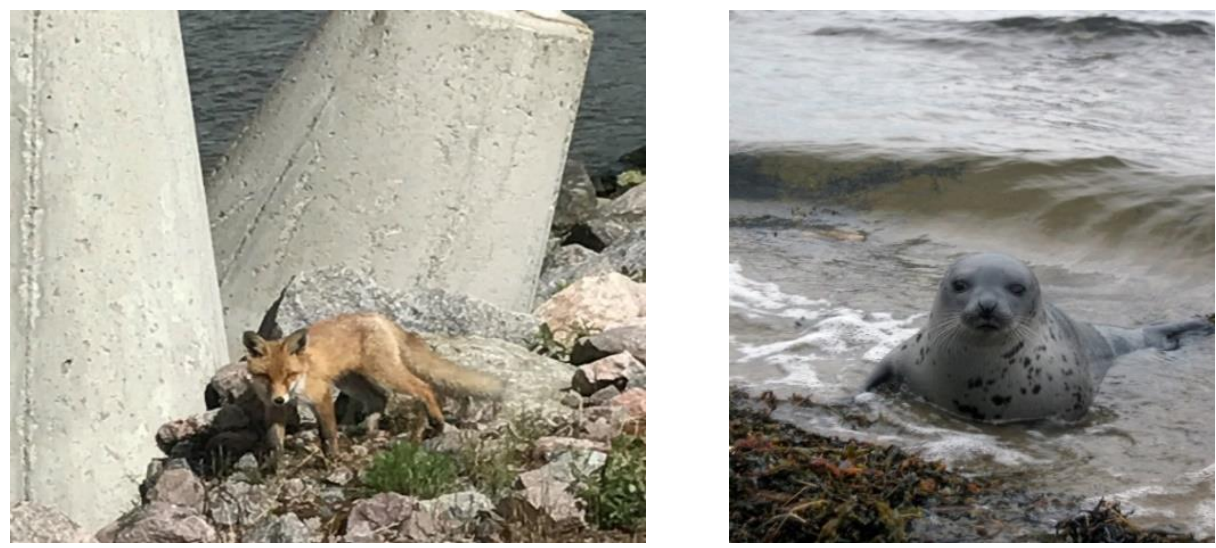

Figure 6 Red fox and seal

For the first time after the completion of construction, in May 2016, a large number of very rare plants listed in the Red book - Primula (Primula) - were grown on the lawns of the KZS. 


\section{CONCLUSIONS}

1. The commissioning of the KZS in 2011 and the completion of the main sewer collector in the Northern part of the city were the main factors contributing to the purification of the Neva Bay and the Neva river Delta. Currently industrial and municipal water discharges in the Neva river are 100 purified\%.

2. At present, the Neva Bay is separated from the Gulf of Finland by protective structures of exceptional environmental significance. Culverts with a total living area of $9540 \mathrm{~m} 2$ and a spillway front of $1864 \mathrm{~m}$, which is 1.5 times larger than the mouth of the Neva river.

3. KZS gates are always open in their normal state, providing full "transparency" for the free movement of water and biota between the Gulf of Finland and the Neva Bay. The system of currents, wave and temperature regimes, the natural regime of water levels in the Neva Bay and the Delta of the river. The Neva river has not changed. As in everyday life, there are constantly marked levels well below the ordinary. Flooding of the city does not occur.

4. If there is a threat of flooding, all ship and culvert structures of the protective complex cover the Neva Bay, and it turns into a closed water area. The closed gates of the KZS prevent the transfer of a huge amount of bottom sediments from the Eastern part of the Gulf of Finland to the Neva Bay by drift currents. Therefore, there is no pollution of the Neva Bay from the Gulf of Finland. In the Neva Bay itself, during this period, there is an accumulation of runoff of the Neva river.

5. After the flood situation ends, levels are leveled and all gates of protective structures are opened, when the level drops, the Neva river, unlike the living conditions, no longer carries water with a high concentration of pollutants into the Neva Bay.

6. Implemented design solutions have created favorable conditions for the successful recovery of the ecosystem after entry to the GLC in operation.

7. Successful operation experience confirmed the conclusions of scientists, designers, and an International Commission of independent experts on the environmental safety of protective structures.

8. Experience of the KZS operation clearly shows that the environmental safety of the water area and adjacent territories contributed to the rapid restoration of the ecosystem after the completion of the KZS construction.

\section{REFERENCES}

[1] Migurenko, V.: “Actual problems of Flood Protection Barrier maintenance", Гидротехническое строительство, 2015, No. 8, pp. 56-58.

[2] Popov, V., Monosov, L.: "Technical supervision in the Project of Flood Protection Barrier completion", Гидротехническое строительство, 2013, No. 5, pp. 18-22.

[3] Popov, V., Monosov, L.: "Five years operation main results of St. Petersburg Flood Protection Barrier”, Znanstvena misel journal, 2017, No. 4, pp. 126-133.

[4] Monosov, L., Popov, V.: "To environmental issues when summarizing the experience of designing, building and operating of Flood Protection Barrier in Saint Petersburg", Materials of the IX International scientific and practical conference on June 102018 , Yekaterinburg, pp. 36-46. 